\title{
Ungdomslitteratur former(er) sig
}

Ungdomslitteratur udvikler sig i dialog med digitale og mediebaserede impulser og er i disse år i gang med at forme(re) sig, dels igennem en udvidelse af sit felt, dels igennem en optagethed af og refleksion over sin form. Formorienteringen accentueres især ved en indoptagelse af og forholden sig til unges liv med og imellem medier. Denne artikel fokuserer på, hvilke konsekvenser for udsigelserne om ungdomsliv og for ungdomslitteraturs æstetik og mulige egenart, som denne udvikling medfører. Undersøgelsen og diskussionen tager udgangspunkt i N. Katherine Hayles' teori om den mediespecifikke analyse, som fokuserer på forholdet mellem form, indhold og medie (Hayles 2002, 2008). Analysen indeholder en diskussion og nuancering af Hayles' triade, og i stedet præsenteres en mediesensitiv tilgang, som orienterer sig imod, hvordan romanen materialiserer sig og dermed møder sin læser. Denne materialitetstilgang har ikke tidligere været anvendt i læsninger af ungdomslitteratur eller i diskussioner af ungdomslitteraturens mulige egenart.

Først vil jeg foretage en række nedslag i aktuelle danske ungdomsromaner, som på forskellig vis har en særlig optagethed af mediers rolle i de litterære karakterers liv, hvilket får konsekvenser for romanernes formsprog og udsagn. Mine iagttagelser bliver sat i relation til aktuelle teoridannelser om ungdomslitteratur. Dernæst følger en mediesensitiv analyse af Ronnie Andersens roman Akavet (2014) med samme fokus, kombineret med en analyse af den denaturalisering ${ }^{\mathrm{I}}$ af læseprocessen, som romanen medfører i kraft af sin udformning. Overordnet vil jeg undersøge, hvilket billede af ungdomsliv og hermed subjektforståelse og -konstruktion disse romaner for eller med unge tegner, og hvilke mulige implikationer dette har for ungdomslitteraturbegrebet.

En fremherskende tese i teori om ungdomslitteratur er, at denne litteratur drejer sig om den unges udviklingsproces fra barn til voksen og dermed skildrer en overgang præget af linearitet, modning og vækst (Nikolajeva 2000, Gansel 2000, Trites 2000, 2014). Trites viser i sit seneste studie, hvordan forestillingen om vækst manifesterer sig i ungdomslitteratur, og "how growth serves as a cognitive concept 
that structures our ability to think about adolescence as literary critics" (Trites 2014, 7). Jeg vil imidlertid argumentere for, at der også er ungdomslitteratur, der fortæller om en ungdomstilstand og -stilstand ved at blive realiseret på andre præmisser. Blandt andet i kraft af mediers tilstedeværelse i litteraturen og i de unge hovedpersoners liv kan disse romaner ses som eksponenter for en bevægelse fra ungdomslitteratur som fortællinger om 'coming of age' til 'being in age'. Nærværende artikel baserer sig på tidligere og aktuelle iagttagelser af narrative mønstre i ungdomslitteratur og søger ikke at underkende tendensen til at skildre vækst og udvikling, men den viser samtidig, at der også er ungdomslitteratur, der ikke inkorporerer dette mønster og hverken indoptager dannelses- eller udviklingsromanmønstret. Nyere eksempler viser i stedet billeder af ungdomsliv i en øjeblikkelig og punktuel form, særligt tilvejebragt af mediers tilstedeværelse. Ungdomslitterære fortællinger om 'being in age' skildrer en ungdomstilstand lige her og lige nu.

\section{Medier i ungdomslitteratur}

'Ungdomslitteratur' er en flydende betegnelse, der defineres forskelligt i forskellige sammenhænge og ud fra forskellige hensyn: Bibliotekernes behov for klassifikation, forlagenes behov for målgrupperettet markedsføring og endelig værkernes egenart kan pege i mange retninger. Aktuelt kan man iagttage en øget åbenhed og usikkerhed omkring ungdomslitteraturbegrebet, idet der er opbrud i grænserne mellem børne-, ungdoms- og voksenlitteratur, hvilket fx ses i crossover-tendenser mellem genrer, tekster og læsere, i graphic novel og Young Adult- eller YA-betegnelsens fremkomst. ${ }^{2}$ Dertil kommer, at litteratur for unge i stigende grad knytter an til unges liv med og imellem medier, hvilket kan ses i fx formeksperimenter med integration af tekstsekvenser fra sociale medier, sms-korrespondancer, fotos og forskellige former for grafik. ${ }^{3}$ Romaner for og med unge ser ud til i særlig grad at referere til og integrere andre medier og populærkultur, særligt med intertekstuelle referencer til rock- og popmusik.

Aktuelle eksponenter for nogle af disse tendenser er fx 21 måder at dø på af Sarah Engell (2014) og Niviaq Korneliussens HOMO sapienne (2014). I 21 måder at dø på demonstreres det, hvordan mobning kan foregå og accelerere i det virtuelle rum. Hovedpersonen Stella går på kort tid fra at have venner og succes til at blive udstødt og hånet på sociale medier i så høj grad, at hun planlægger sin egen død og seriøst overvejer og ranglister de 21 bedste måder at begå selvmord på, inspireret af hjemmesiden takethislife.com. I HOMO sapienne integreres sms-korrespondancer, facebookopdateringer og fotos (portrætterende forfatteren!) (se billede 1), ligesom der er henvisninger til fem musiknumre på youtube.com, som akkompagnerer romanens fem kapitler, der er fortalt af fem forskellige fortællere. Som titlen antyder, så tematiserer HOMO sapienne det at være (et ungt) menneske, men med et særligt tvist i retningen af accentueringer af køn, femininitet, seksualitet og samhørighed.

I de to nævnte romaner, hvoraf den første indgår i det ungdomslitterære kredsløb og den anden i det voksenlitterære, spejler romanerne således ungdommelige oplevelser og følelser både i indhold og på ord- og formniveau. Det samme gør sig gældende for Christine Lind Ditlevsens fredag lørdag søndag (2015), der skildrer 


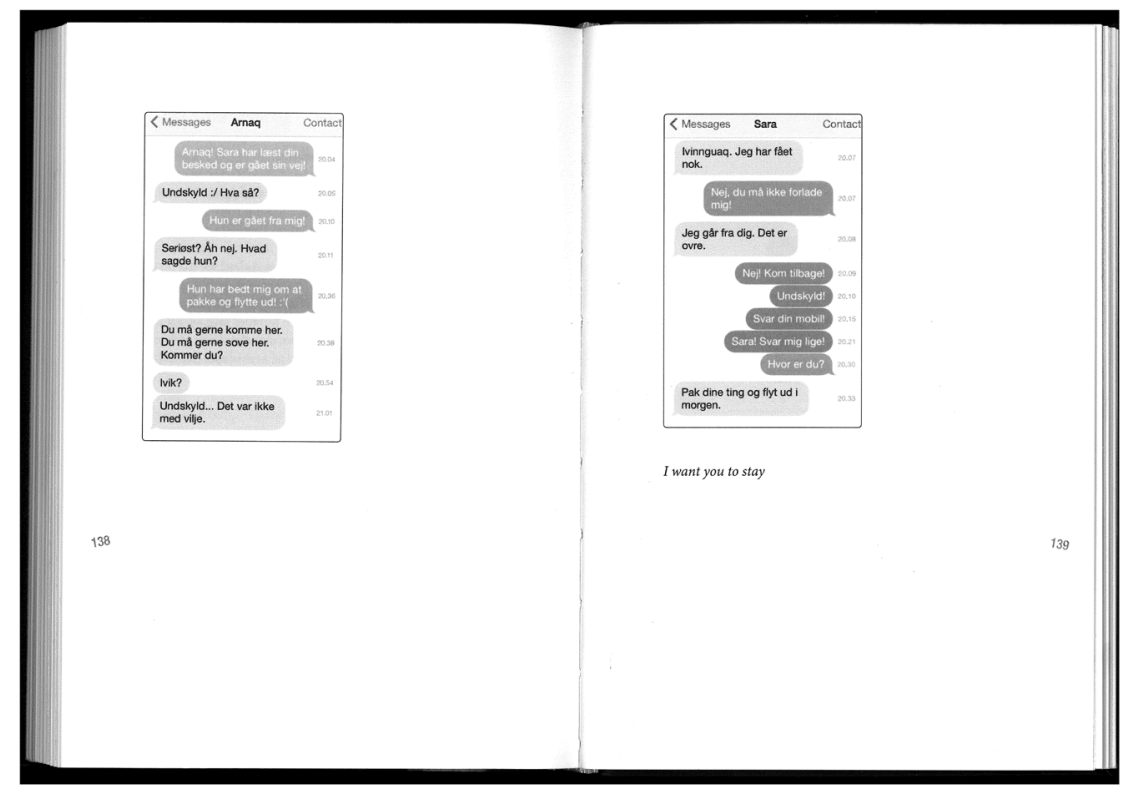

Billede 1: Sms-korrespondancer i Niviaq Korneliussens HOMO Sapienne (2014)

en weekend i hovedpersonen Kats liv. Mediers påtrængende tilstedeværelse gennemsyrer romanen, og hovedpersonen oplever nærmest et eksistentielt nulpunkt, da hendes mobiltelefon bliver smadret, og hun ikke kan komme på de forskellige sociale netværkssider og dermed vedligeholde kontakt med omverdenen. I sekvenser gengives livet med og imellem medier i stream of consiousness, hvor statusopdateringer og tankefragmenter associativt vælter ind over hinanden:

Billie vil bare chille, [...], MØ stater: OMG 1/4 million likes. Pretty awesome. I love you. Stine poster fra JOE \& THE JUICE på Købmagergade, SKYGG poster fra Soundcloud: God weekend, husk at tagge, fortælle nogle og råbe acab, når du ser solen stå op [...]. Jeg poster en selfie med Holmbladsgade i baggrunden og kvalme. Min hjerne er en dødvægt, intet er pludselig basic. (Ditlevsen 2014, 115-116)

Samtidig inkorporerer romanen temaer som tab af uskyld, fremmedgjorthed, savn, sorg, smerte og kærlighed, som alle ofte er forekommende i ungdomslitteratur. fredag lørdag søndag bliver nærmest et sindbillede på en ungdommelig tilstand, præget af rast- og rodløshed grænsende til desperation, men også intens lykke og glæde.

Det samme gør sig gældende i Andersens roman Akavet, hvor hovedpersonen Mikke fortæller. Han lider af social angst og tager omverdenens impulser ind i så høj grad, at reklameslogans og musikfragmenter konstant glider ind over hans usorterede tankestrøm, imens han sidder i et tog mellem "Hjemmet", som er det behandlingshjem, han bor på, og sit egentlige hjem. Han føler sig dog hjemløs begge steder. Romanens spejling af den medievirkelighed, der omgiver unge, sætter sig igennem på formniveauet, hvor henvisningerne til musiknumre står som kursiverede, venstrestillede sætningsfragmenter. Derudover ekspliciteres varemærker, og deres slogans gengives med mindre, hævede versaler, og på humoristisk vis angives af og til "Ukendt mærke" (se billede 2). Disse to elementer fremstår som fiktionsbrud, der 


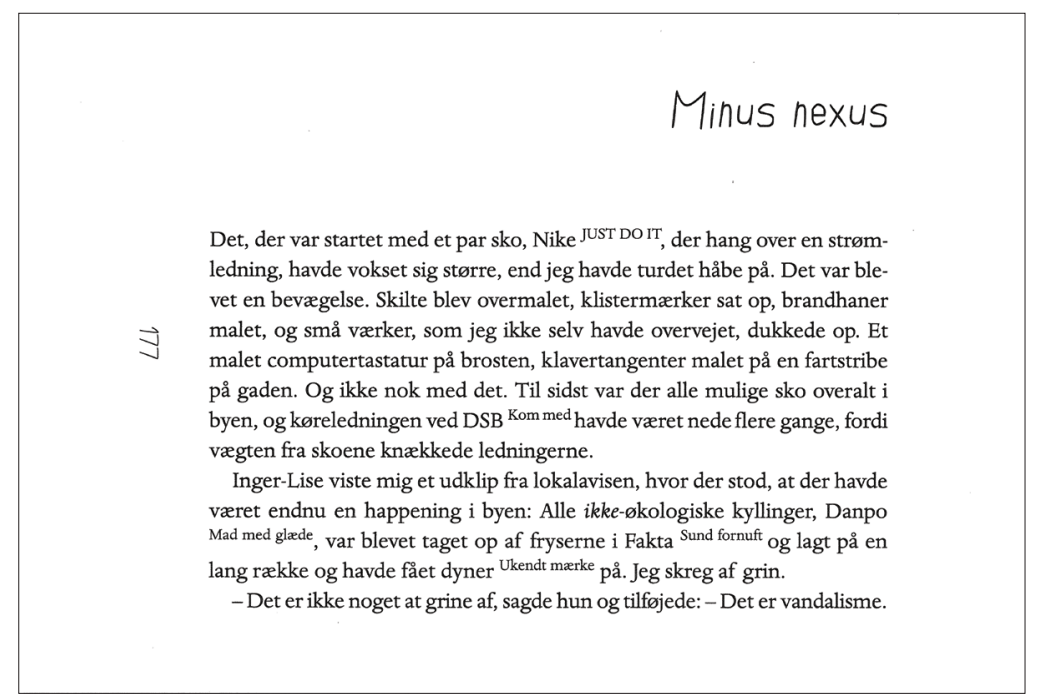

Billede 2: Varemærker og slogans i Ronnie Andersens Akavet (2014)

skaber ophold i indlevelsen og autenticiteten, og fortællingen gør dermed opmærksom på sig selv og den allestedsnærværende mediekontekst, den og dens læser er en del af. Læseren rives for en stund ud af indlevelsen, men ved at mime virkeligheden helt ned i den mindste mediedetalje skabes derefter måske endnu større autenticitet?

De fire romaner har forskellig valorisering af mediernes tilstedeværelse i de unges liv: Hvor 21 måder at dø på kritisk viser mulige konsekvenser, når den mellemmenneskelige kommunikation foregår i et depersonaliseret rum, integrerer de tre andre romaner den unges liv med og imellem medier som et vilkår og viser, hvordan omgangen med medier er en form for selvudtryk og bidrager til dannelse af individualitet og identitet. Romanerne skriver sig ind i en nyere tendens, som Victoria Flanagan har iagttaget: Hun fremhæver et paradigmeskifte i ungdomslitteratur, der fra at have fulgt en antiteknologisk agenda, hvor teknologiske fremskridt blev tilgået med angst og skepticisme, nu ser unge menneskers involvering med teknologi som noget positivt og potentielt frigørende (Flanagan 2014). ${ }^{4} 21$ måder at dø på placerer sig $i$ dette perspektiv i den tidligere forståelse, hvorimod HOMO sapienne, fredag lørdag søndag og Akavet på forskellig vis demonstrerer, hvordan den teknologiske udvikling er med til at forandre den menneskelige identitet og eksistens. Fælles for de fire romaner er, at de viser, hvordan ungdomslitteratur i stigende grad orienterer sig mod og er bevidst om sammenhængen mellem form og indhold, både i forhold til romanernes fysiske, materielle udformning og på det stilistiske og ordmæssige niveau.

\section{Teoretisk ramme for ungdomslitteratur}

Særligt i de seneste 20 år er ungdomslitteraturs æstetik og mulige egenart blevet undersøgt og diskuteret (Nikolajeva 1996, 2000, Gansel 2000, Coats 2004, Trites 2000, 2014, Kampp 2002, 2004, Falconer 2009, Flanagan 2014), om end teoridannelser, præciseringer og differentieringer i dette felt stadig efterspørges (fx Coats 2011, 315 og 322, Ewers 2013, 71). Karen Coats fremhæver, at både unge og forskningen i ungdomslitteratur kan betegnes som værende i en liminal og udgrænset 
position (Coats 2011, 315). Hun efterspørger "a more robust critical conversation [...] that treats YA literature as a destination literature, rather than an in-between phenomenon that is useful for pedagogical applications" (ibid., 317). Som nævnt har forskningen fremhævet, at ungdomslitteratur tematiserer ungdommens udviklings- og modningsproces. En fremherskende tese er, at ungdomslitteratur udtrykker hovedpersonens søgen efter en fast væsenskerne, og at den handler om udvikling og erhvervelse af identitet, handlingsautonomi, social ansvarlighed og etisk engagement (Gansel 2000, 377 og Coats 2011). En stærk teoridannelse i den ungdomslitterære forskning, tydeligst formuleret af Maria Nikolajeva, anser ungdomslitteratur som den unges quest, forstået som den unges søgen efter at finde og erkende sig selv i en marginal position mellem barndom og voksenhed. Nikolajeva har iagttaget og pointeret, at ungdomslitteratur er karakteriseret ved linearitet, irreversibilitet og gennemlevelse af initiation, forstået som en symbolsk skildring af en modningsproces (Nikolajeva 1996, 2000). Ungdomslitteratur bliver således set som litteratur, der skildrer en overgang og kan betegnes som "coming of age"fortællinger.

I et af de seneste bidrag til ungdomslitteraturforskningen viser Roberta Seelinger Trites ud fra kognitiv lingvistik og narratologi, hvordan "growth" både som metafor og som narrativt mønster er allestedsnærværende i ungdomslitteratur (Trites 2014). ${ }^{5}$ I sit tidligere bidrag til feltet, Disturbing the Universe (2000), kom Trites frem til, at hovedpersonen i slutningen af de fleste ungdomsromaner enten er modnet til en grad af konformitet eller er død (Trites 2000, 1). I sin videreudvikling af denne teori undersøger hun begrundelsen for dette forhold i ungdomslitteratur og konkluderer, at "growth" har hegemonisk tilstedeværelse i betydningen at modnes, vokse op og udvikle sig, som konnoterer noget positivt og har en dyb kulturel indlejring, og hun ansporer kritikere til at forholde sig til validiteten af denne konceptualisering (Trites 2014, 123-145). I den ungdomslitterære forskning er der således ansats til kritik af tidligere antagelser, men det er der også i de ungdomslitterære værker selv. Megen ungdomslitteratur inkorporerer de nævnte tendenser og mønstre, men man kan også iagttage værker, der skriver sig op imod sådanne definitioner, og som realiseres på andre præmisser. De udtrykker ikke udvikling, modning og linearitet, men i højere grad stilstand, midlertidige tilstande og væren (grænsende til hjemløshed) i tilværelsen. Akavet er et eksempel på det sidste.

\section{En akavet ungdomsroman}

Som anført følger læseren af Akavet jegfortælleren Mikke (der egentlig hedder Mikkel) på en togrejse mellem behandlingsstedet "Hjemmet", hvor han bor på grund af psykiske problemer, og hans rigtige hjem. Han kan ikke huske, hvilken destination han er på vej til. I romanen klippes der mellem togrejsen og tilbageblik på hans liv, hvor mødet med pigen Karla og mormorens strikkeklub, der har leveret materiale til Mikkes oprør i den lokale by, har stor betydning, samtidig med at musiknumre og reklameslogans maser sig indover. Formen er dermed fragmenteret og tumultarisk og afspejler hovedpersonens mentale tilstand og hans tilgang til verden, som han selv allerede i romanens anslag beskriver som "uden filter": "Mennesker 
er som cigaretter: De kommer med eller uden filter. Der er ingen tvivl om, at jeg er en af dem uden filter..." (Andersen 2014, 5).

Den formmæssige fragmentering og grundfølelsen af anderledeshed udspiller sig ikke blot på det sproglige niveau, men tillige i romanens fysiske udformning, idet den skal læses vendt 180 grader. Allerede omslaget indicerer akavethed og uro, blandt andet i kraft af kælkede linjer og en ko med lilla pletter, der kigger ud på læseren. Samtidig påberåber titlen sig særlig opmærksomhed, dels ved at bestå af et lidt altmodisch adjektiv, der betyder "ubehjælpsom, klodset, forkert, bagvendt", dels ved at denne anderledeshed materialiseres gennem valget af typografi, der minder om en skødesløs håndskrift og gentages med en lidt anden lemfældig typografi på titelbladet. Samme typografi indleder hver kapiteloverskrift. I det hele taget er Akavet karakteriseret ved anvendelse af en række forskellige typografier og igennem disse ved en formbevidsthed, som udspiller sig på både det ordmæssige og materielle niveau. Derfor forekommer det oplagt at foretage en analyse, der inkorporerer sensitivitet i forhold til (bog)mediet og dets materialitet.

\section{En mediesensitiv tilgang til litterær analyse}

N. Katherine Hayles pointerer i sin bog Writing Machines (2002), at den litterære kritik altovervejende har set og ser litteratur som "immaterial verbal constructions" (Hayles 2002, 19). Bortset fra forskning i kunstbøger og konkret poesi har bogen som et fysisk objekt været underbelyst ifølge Hayles, og hun iagttager, at fremvæksten af elektronisk litteratur gør det endnu mere oplagt og presserende at placere det litterære artefakts materialitet centralt i de litterære studier. En af Hayles' pointer er, at man ved at undersøge litteraturens materialitet kan få et mere nuanceret billede af, hvordan litteraturen er under forandring og få et nyt blik på den ældre litteratur (Hayles 2002, 2008). Hayles er ikke alene om denne pointering af en manglende sammentænkning af litteratur som sprogkunst og materiel form. Forskning i litteraturens materielle dimensioner har pågået fra så forskellige positioner som editionsfilologi og boghistorie (Malm, Sjönell og Söderlund 2009), studier af bogobjektet og litterær materialisme (McGann 1991, Brügger 2003, Brown 2010), og denne nyligt opståede interesse lægger sig ligeledes i forlængelse af den generelle orientering hen imod materialitet, som har kunnet iagttages i de senere år indenfor bl.a. arkæologi-, kultur- og antropologiforskning (Miller 2006, Damsholt, Simonsen og Mordhorst 2009, Bille og Sørensen 2012, Munster 2014). I børnelitteraturforskning har materialitetsperspektivet heller ikke været negligeret. Billedbogsforskningen har fx i mange år inddraget analyser af billedbøgers materialitet, forstået som analyser af billedbogens format, for- og bagside, forsats og bagsats m.m. og har anskuet billedbogen som et medie (Rhedin 1992, Christensen 2003 og 2014, Druker 2008). ${ }^{6}$ Børnelitteraturforskningen har imidlertid ikke begrebsliggjort denne analyse med termer som Hayles' eller anvendt materialitet som begreb, og i forhold til analyser af ungdomslitteratur har materialitet ikke fået opmærksomhed. Derfor forekommer det oplagt at tage udgangspunkt i Hayles' position for at undersøge ungdomslitteraturs former og måder at materialisere sig på, fordi de har afgørende betydning for både betydningsdannelsen og læseprocessen. 
For at nærme sig litteraturens materialitet introducerer Hayles "Media-Specific Analysis: a mode of critical interrogation alert to the ways in which the medium constructs the work and the work constructs the medium" (Hayles 2002, 6). Omdrejningspunktet i Hayles' mediespecifikke analyse er altså gensidigheden mellem værk og medie samt triaden mellem form, indhold og medie (ibid., 31). Hermed tillægges mediet - som kan være papirbåret eller digitalt - en afgørende og hidtil ikke særlig synlig rolle i den litterære analyse. I den følgende analyse tager jeg udgangspunkt i dette øgede fokus på mediets betydning. Imidlertid forekommer sidestillingen af form, indhold og medie at have en risiko for opskrivning af form- og mediemæssige aspekter ved det litterære artefakt på bekostning af dets indholdsmæssige udsagn. Derfor vil jeg foreslå en vægtforskydning i Hayles' triangulering mellem form, indhold og medie, således at mediet i stedet bliver den optik, det komplekse forhold mellem indhold og form samt mellem tekst og læser anskues igennem:

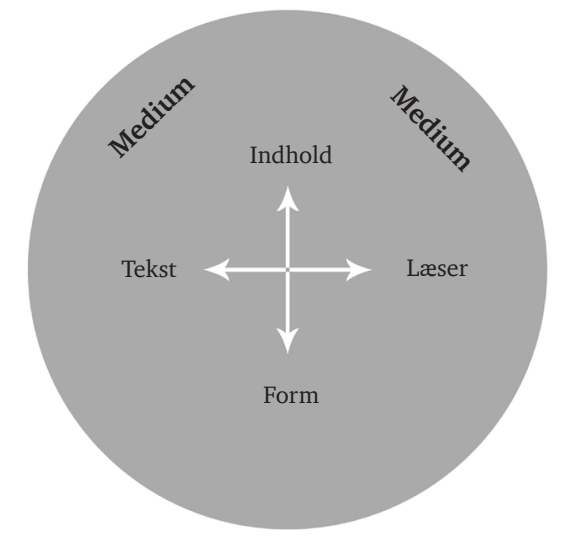

Model over de forskellige fikspunkter i en mediesensitiv tilgang, hvor mediet danner klangbund for at begribe værket.

Modeller er altid forsimplinger af langt mere nuancerede forhold, men modellen her skal understrege vigtigheden af et ligeværdigt forhold mellem indhold og form samt tekst og læser i en læsning, hvor mediet danner klangbunden for at begribe værket. Med andre ord kan den analytiske tilgang her karakteriseres som en mediesensitiv metode, idet den er særlig fintmærkende i forhold til mediet og anerkender, at et værk (også) må forstås i kraft af dets materialitet. Imidlertid vil den mediesensitive tilgang ikke opskrive mediet til en akse i en triade sammen med form og indhold, men i stedet lade mediet være den baggrund, som de nuancerede relationer mellem form og indhold samt mellem tekst og læser indgår i og skal begribes ud fra. Samtidig giver den mediesensitive tilgang mulighed for at fokusere på artikulationen af læseren i mødet med mediet, dvs. bogobjektet i nærværende analyse. Jeg undersøger læserens positionering og medskabende betydning i læseprocessen ud fra Wolfgang Isers teori om læserappel og -respons (Iser 1971, 1978) og den videreudvikling, som Hans Kristian Rustad har foretaget heraf i forhold til læsning af hyperfiktion (Rustad 2009), dvs. digital fiktion med en åben struktur. Med udgangspunkt i en række begreber fra Hayles, som anvendes i analytisk øjemed, og ud fra en mediesensitiv tilgang vil jeg lave en række analytiske nedslag i Akavet af Ronnie Andersen 
med henblik på at undersøge, hvordan ungdomsromanen reflekterer over sine materielle forudsætninger, og hvad det medfører for romanens samlede udsigelse, for læserens positionering, og for hvordan den konstituerer sig som ungdomsroman.

\section{Ungdomsbogen som medie og begreb i Akavet}

Ifølge Hayles er bogen som objekt en "materiel metafor". Med dette begreb vil hun sætte fokus på "the traffic between words and physical artifacts" (Hayles 2002, 22). Papirbåret litteratur er indlejret i fysiske og historiske konventioner, der fx strukturerer definitionen af en side og læseretning. Akavet spiller tydeligt op imod sådanne konventioner, for det første ved at den skal læses vendt 180 grader, dvs. vertikalt, for det andet ved at teksten har en række forskellige typografier, og for det tredje ved gentagelser af betydningsfulde ord som fx Akavet (sat med skrifttypen Dante), TAK FOR ADVARSLEN og Angsten (sat med Helvetica). Ved at skulle læses vertikalt og gennem de forskellige typografier uselvfølgeliggør romanen på det materielle og det formmæssige niveau det selvfølgelige, hvilket radikaliserer den følelse af fremmedgjorthed, som kendetegner hovedpersonen. Bogmediet og formen er akavet og anderledes, og det er den samme eksistentielle grundfølelse, som Mikke har: Han føler sig akavet (fx er hans navn ufuldendt), hans tanker og handlinger er akavede (han gør og siger ting som er uden for hans kontrol), og romanen er i sin materialitet akavet. Relationerne mellem form og indhold og mellem tekst og læser er dermed afgørende påvirket af bogmediet, og de fire elementer lever i symbiose og tildeler hinanden betydning. Akavet udgør i dette perspektiv en materiel metafor på det til tider absurde og akavede (ungdoms)liv.

Umiddelbart er det vertikale format det mest iøjnefaldende konventionsbrud ved Akavet som materiel artefakt, men ordenes visuelle fremtrædelse og en række gentagelsesstrukturer har større betydning for romanens samlede udsigelse. Igennem en bred palet af forskellige typografier, kursiveringer, anvendelse af versaler og af fed skrift samt spatieringer opskrives ord og sætningers visualitet - de bliver til 'wordimages’7 med Hayles' begreb (ibid., 65). Når begrebet Angsten skrives med en anden typografi end resten af romanen, gentages et utal af gange igennem romanen og indgår i gentagelsesvariationer som "angst. Panikangst. Socialangst. Angsten for angst. Men det kunne også være stress. Angststress?” (Andersen 2014, 17), kommer angsten som et grundvilkår for mennesket til at udgøre et grundlæggende udsagn i romanen. Angsten bliver et visuelt og sprogligt/verbalt ledemotiv - både som fænomen (indhold), betegnelse/ord (udtryk) og som 'ordbillede'/wordimage. Gentagelserne medfører en form for rytme i romanen, og de typografiske ændringer fører til små metafiktive fiktionsbrud. Wordimages og gentagelsesstrukturer skaber emfase og et særligt slægtskab mellem romanen og den lyriske form. Lige så præsent er dette slægtskab imidlertid også på indholdssiden, hvor Akavet i langt højere grad formidler en tilstand end en proces og dermed ikke inkorporerer den linearitet og det 'coming of age'-narrativ, som ellers er karakteristisk for ungdomslitteratur ifølge en del af forskningen.

Som anført tidligere baserer ungdomslitteratur sig på en quest-struktur og er ifølge Nikolajeva ofte karakteriseret ved gennemlevelse af initiation. Inspireret af myte- 


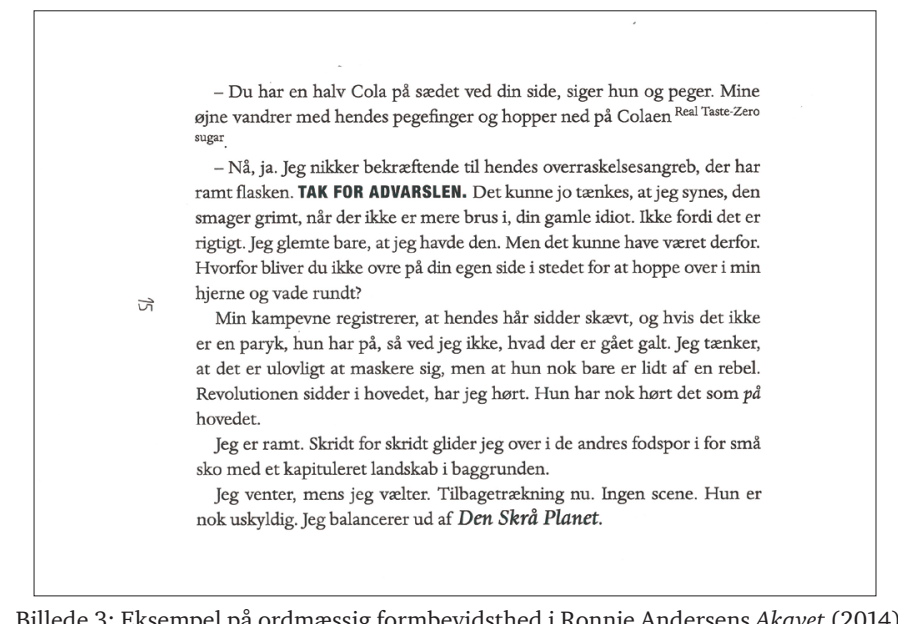

der sker en aktualisering af primitive folkeslags initiation vedrørende det sakrale, døden og seksualiteten, hvorigennem den unge bliver indviet til voksenverdenen (Nikolajeva 2000, 6, 212). I Akavet er initiationselementerne helt konkret til stede i form af den akavede præst Taala, der med sine spørgsmål bliver en form for katalysator for Mikkes refleksioner over livet og døden, Gerdas død og Mikkes besøg på kirkegården med øldrikning og "samtaler" med den døde Helle - "mit personlige Helle" (Andersen 2014, 57). Dertil kommer, at seksualiteten beskrives ubesværet igennem forholdet mellem Mikke og Karla, og heller ikke de små homoerotiske erfaringer fremstilles som hverken grænseoverskridende eller problematiske. Alligevel fremstår Akavet ikke som en initiationsroman per se, idet der ikke er en egentlig fremdrift, plot eller linearitet i romanen. I det lys fremstår Akavet også som ungdomslitteratur akavet, idet den i sin opbrudte fremstillingsform kun skildrer et udpluk af en togtur og som fortælling gennem flashbacks formidler nogle klip fra et liv, som læseren kan stykke sammen, men som i højere grad skildrer en mental tilstand end en udviklingsproces. Romanen udgør et limbo mellem et eksistentielt vakuum og et intensivt og eksplosivt udsagn om (ungdoms)liv. Den er kun i begrænset omfang en fremdriftsfuld fortælling, og hvis man læser den for at få tilfredsstillet sit narrative begær, bliver man skuffet. Endda Peter Brooks' klassiske bog Reading for the Plot nævnes på humoristisk og metafiktiv vis (Andersen 2014, 237) i det kapitel, der hedder "Deus ex machina" (ibid., 231), og hvor denne forestilling om guddommelig indgriben netop ikke indtræder og løser konflikterne. På den måde peger romanen på sig selv og tematiserer sit eget begrænsede plot og narrative fremdrift, hvilket også understøttes af, at Mikke fortæller historier uden pointer (ibid., 175) og af endnu en kapiteloverskrift "Minus nexus": Et af flere grundlæggende udsagn i Akavet synes at være, at der ikke altid er logisk og ligefrem forbindelse mellem elementerne i Mikkes historier, mellem elementerne i romanen og mellem elementerne i et menneskes liv.

\section{Hypertekstualitet. En roman om at være en roman og om at være ung}

Hayles udvikler i Writing Machines begrebet 'technotext' til at forene forståelsen af litteratur som verbal kunst med et fokus på dens materielle form. Betegnelsen henfører hun til litteratur, som "interrogates the inscription technology that produces 
it" (Hayles 2002 , 25). Helt grundlæggende indgår alle litterære værker i en relation mellem den fysiske form og ordene, men nogle værker tematiserer denne relation, og det er disse, Hayles betegner som teknotekster. I hendes materiale er teknoteksterne også alle hypertekster (ibid., 26). Som nævnt er der i Akavet en høj grad af interaktion og gensidig meningstilskrivelse mellem romanens fysiske form og indholdet. Akavet er ikke, som det er tilfældet med mange af de litterære tekster, Hayles unders $\emptyset$ ger, en avanceret elektronisk hypertekst med fx forskellige læseveje og avancerede linkstrukturer (ibid., 26). I det hele taget er der ikke i Akavet et komplekst forhold mellem skærmoverfladen og den teknologi, hvormed teksterne er indskrevet, som tilfældet er med digital litteratur. Alligevel leger romanen med sin måde at være i verden på, og idéen om hypertekstualitet tilvejebragt af tekstens materialitet kan derfor pege på forskellige tekstniveauer, som også er aktuelle i Akavet.

For det første er der romanens fysiske beskaffenhed, dens stoflighed. Ved at være en papirbåret bog, aktiverer den syns-, lugt- og følesans og dermed også en række traditionsbårne måder, hvorpå læseren lagrer erfaringer og viden. Romanen er i kraft af sin fysikalitet gennemsyret af ubevidste forventninger, som Akavet på én gang både skriver sig ind i ved at imitere en traditionel roman i sit format fx højde, bredde og tykkelse og spiller op imod igennem det konsekvent vertikale læseformat fra titelbladet og frem. På den måde kommer romanen til at befinde sig i et skisma mellem den traditions- og papirbårne bog med sider, som læses horisontalt, og hvor man bladrer i øverste højre hjørne, og det moderne digitale, computerbårne dokument, hvor man scroller ned i en principielt uendelig tekst. Skismaet understøttes af romanens sidetal, som er placeret traditionelt midt på siderne ud fra en bogoptik, men er sat med den håndskriftsimulerende typografi fra forsiden og kapiteloverskrifterne. Akavet er på det fysisk materielle niveau splittet mellem at være en konventionel roman og at referere til et digitalt dokument, der skal læses på en skærm.

For det andet udgør tekstens fremtrædelse også et materielt niveau. På hypertekstuel vis gør Akavet opmærksom på dette, fx i kraft af selvrettelser i form af overstregninger som "hvis når" (Andersen 2014, 41) og "det har jeg en hel strikkeklubs ord for..." (ibid., 133) samt ubeslutsomhed i forhold til ordvalg "/udskrevet/ afviklet/ hjemsendt/ frikendt/ fyret/ udkommanderet/ rekrutteret/ afsluttet/ fuldbyrdet/ opsagt" (ibid., 118). Hermed bliver såvel hovedpersonens konstante tankeafbrydelser, selvkorrektion og sproglige valg som romanens tilblivelsesproces tematiseret og visualiseret. Skriften både formidler og peger på sig selv som formidlende instans, og den momentane og tumultariske tilstand hos Mikke understreges i såvel form som indhold.

Akavet er ikke en hypertekst i ordets oprindelige definition af Teodore H. Nelson fra 1965 som "a body of written or pictorial material interconnected in such a complex way that it could not conveniently be presented or represented on paper" (Nelson 1965, 96), men den mimer i sekvenser hypertekstens linkstruktur (se billede 4). Gennem "citations and imitations of one medium in another" (Hayles 2004, 68) - eller hvad man kunne kalde remediering med Bolter og Grusins begreb - mimer romanen af og til hypertekstens dybde og fragmentering. Det interessante er dog, at disse links ikke er aktive i Andersens roman, hvormed sekvenserne på paradoksal vis 


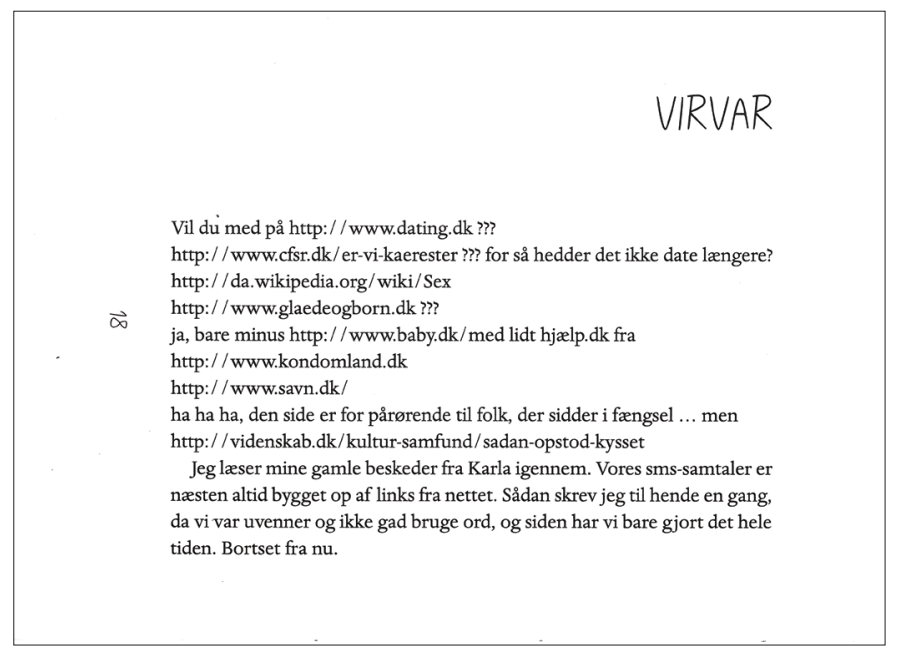

Billede 4: Links i Ronnie Andersens Akavet (2014)

giver sig ud for at være et netværk af krydsreferencer, som reelt er inaktive, flade og lineære, om end deres URL er ægte, hvis læseren afprøver dem i en internetbrowser. Linksene markerer en form for "fiktiv" hypertekstualitet. De er hverken det ene eller det andet, de er i en mellemtilstand eller hjemløse ligesom Mikke. Linksekvenserne er såvel kommunikation mellem Mikke og Karla som markører af hyperfiktion. De tematiserer læseprocessen og indlejrer romanen i en moderne medievirkelighed.

Læserens indlevelse og illusion om den fiktive verden punkteres konstant og ansporer vedkommende til at reflektere over romanen som roman og over hovedpersonens situation igennem materialiteten, som den accentueres såvel i romanens fysiske udformning som i de indre materielle egenskaber, dvs. på udtryksniveauet. Hypertekstualiteten fører dermed naturligt til metafiktion ${ }^{8}$ igennem romanens tematisering af sin egen status af fiktion - sin tilblivelse - og tematiserer forholdet mellem fiktion og virkelighed. Det ses fx i en række scener, hvor fiktionens virkelighed smelter sammen med fantasi og absurditet:

14 Til sidst knækkede nakken, og mit hoved trillede væk. Skeen i sukkerskålen kunne jeg bruge til at grave mit ene øje ud med og balancere øjet ud i køkkenvasken. Det var næsten bedre end at forestille sig, at nogen fandt ens rådne lig i krybekælderen. At de bare fandt et enkelt øje, der stirrede på dem og sagde: Hvad vil du? (Andersen 2014, 97)

Ikke sjældent anvendes stream of consciousness i form af Mikkes usorterede, konstante og associative tankestrømme samt registreringer af omverdenen, eller når kasseapparatets enerverende "Bip. Bip. Bip..." (se billede 5) gentages over tre sider (ibid., 89-91). Sådanne sekvenser tematiserer hovedpersonens emotionelle tilstand igennem en 1:1-gengivelse af hans oplevelse af verden. Sekvenserne medfører desuden, at læserens indlevelse i fiktionen bliver afbrudt, og de bliver en form for tekstuelle modhager. Forholdet mellem fiktion og virkelighed italesættes også helt konkret i Mikkes tanker om "zombierne", som er hans betegnelse for de (såkaldte) almindelige mennesker: "Det var en samtale, et vendepunkt, noget forudsigeligt, der altid skete i zombiernes liv og i fiktive zombiers liv eller i zombiernes fiktive liv" 


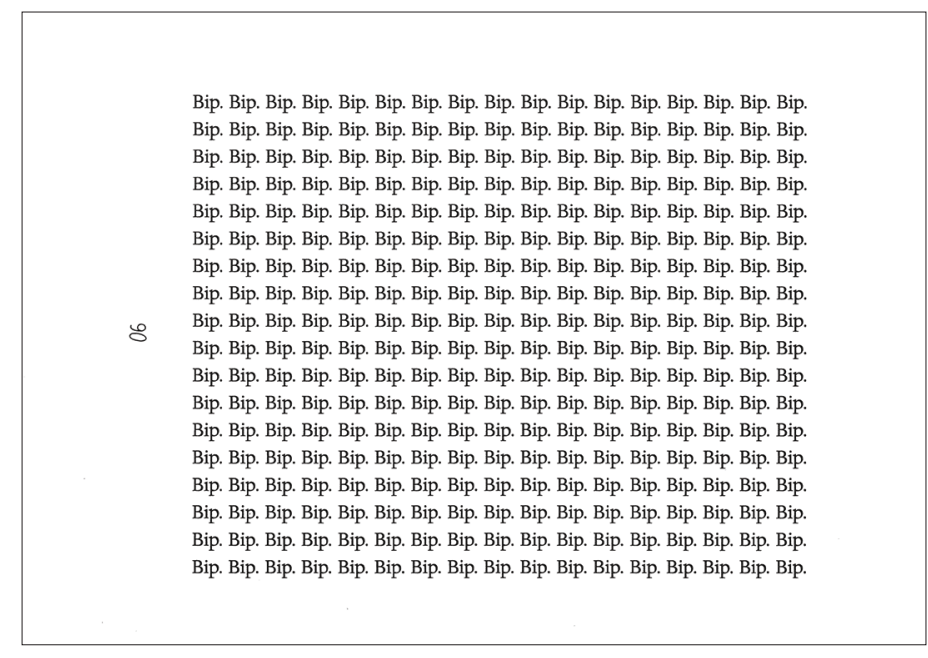

Billede 5: Ronnie Andersen Akavet (2014)

(ibid., 123). Ligesom Mikke befinder zombierne sig i tilstanden af hjemløshed - for deres vedkommende er det imidlertid mellem liv og død.

\section{Denaturaliseret læseproces}

Ud fra en mediesensitiv analyse skal materialitet ikke kun forstås som tekstinterne egenskaber ved litteratur, men som noget, der opstår i interaktionen mellem form og indhold samt tekst og læser, når disse relationer reflekteres igennem mediet. Læserens forventninger til romanformatet såvel som til ungdomsromanindholdet udfordres gennem formen og romanens fysiske egenskaber i Akavet. Læseren inviteres til at interagere med romanen - helt konkret og fysisk - når den skal læses vertikalt, ved de mange forskellige hypertekstuelle træk, men også ved at fx for- og bagsatsbladene er helt sorte, hvor de som oftest i papirbøger er hvide. De sorte sider bliver en form for fysiske "tomme pladser" med Isers begreb (Iser 1971, 1978), der appellerer til undren hos og udfyldelse af læseren. I det hele taget destabiliserer romanen skrevne og uskrevne konventioner for papirbåret litteratur og inddrager dermed sin læser på forskellige måder, som hindrer en udelukkende indlevende læsning. Romanens "læserappel" og dens oplæg til en anderledes "læsehandling" (jf. Iser) iscenesættes gennem dens måde at være i verden på.

Hans Kristian Rustad har med udgangspunkt i især receptionsæstetikken og Wolfgang Iser udviklet en model for læsning af litterære hypertekster, som også kan belyse læserens interaktion med Akavet, selvom Rustads model tager udgangspunkt i elektronisk litteratur (Rustad 2009). Rustads pointe er, at denne form for tekster skal læses på deres egne præmisser, idet de animerer til forskellige læsemåder, hhv. "semantization, exploration, self-reflection and absorption" (ibid., 1), som den enkelte hypertekst kan forudsætte i større eller mindre grad. Den første og helt grundlæggende læsemåde (semantization) er orienteret imod at finde mening og helhed, hvilket Akavet opfordrer til, samtidig med at det er den form for læsning, romanen udfordrer. Akavet har en vis narrativ struktur, en tydelig fortæller m.m., men den tilfredsstiller igennem sin uafsluttede form ikke læserens narrative begær: Læseren sidder tilbage med flere spørgsmål end svar ved romanens afslutning. 
I stedet opstår en anden og mere eksplorativ læsemåde, som ifølge Rustad fører læserens opmærksomhed over i en mere undersøgende tilgang til teksten (Rustad 2009 , 4). Læseren må opgive sit ønske om kontrol og forudsigelighed i interaktionen med romanen, for selvom Akavet inkorporerer mange af bogmediets karakteristika og dermed giver indtryk af at være en lineær fortælling, så udfordrer og underminerer den sådanne forventninger ved i langt højere grad at være fragmenter af et liv. Dermed inviterer romanen til en undersøgende læsemåde med anderledes læsemønstre, og læseren bliver placeret i samme søgende position som hovedpersonen. Rustads tredje læseform betegner han "selvrefleksion", og den kan iagttages, når "the fictional world appears coherent and reality-like" (ibid., 6). I Akavet forekommer den fiktive verden ikke videre kohærent, men det er netop ved at mime en moderne virkelighed "uden filter", at den gengiver en "virkelighed", sådan som den kan opleves for nogle unge. En realistisk ungdomsroman som Akavet er ikke en virkelighedsefterligning, men en virkelighedsfremstilling, og netop derigennem tematiseres sammenhængen mellem værk og verden samt mellem virkelighedsgengivelse og -skabelse. På den måde opfordrer Akavet til selvrefleksion ved at spørge, hvad virkeligheden overhovedet er for en størrelse.

Endelig identificerer Rustad en fjerde læsemåde, absorption, som spejlvender litterære konventioner igennem manglende kohærens og genregenkendelse samt umuligheden for at skabe en stabil mening, hvilket sætter læseren i en tilstand af forvirring (ibid., 7). Selvom Akavet ikke er helt så radikal i form af ulæselighed eller vilkårlighed som de elektroniske tekster, Rustad analyserer, så udfordrer den litterære og kulturelle konventioner og forventninger. Målet bliver dermed ikke at nå slutningens totale meningstilskrivelse. I stedet træder selve læseprocessen eller -rejsen frem som et mål i sig selv, hvilket spejles i Mikkes togrejse: At læse er (også) en rejse, hvor man ikke altid kender destinationen.

\section{Ungdomslitteratur former(er) sig i dialog med andre medier}

Ved at undersøge, lege med og udfordre bogens måde at være bog på skriver Akavet sig ind i en gensidig dialog og spejling mellem bogmediet og andre medier. Akavet kan ses som ét eksempel på, hvordan ungdomslitteratur er i færd med at udvikle og redefinere sig selv ved at afprøve forskellige æstetiske og fortællemæssige strategier, hvor bogmediet er påvirket af andre mediers og genrers strategier, fx dokumentets og hypertekstens. I den unge læsers realisering af romanen knytter den an til dennes liv med og imellem medier. Imidlertid er det ikke blot en neutral indoptagelse heraf, men en understregning af medier som et vilkår i nutidige ungdomsliv og en immanent kritik af forbrugersamfundet særligt tilvejebragt af de påtrængende varemærker og deres logoer samt en ironisering herover med det af og til fremkomne "ukendt mærke".

Ungdomslitteratur er ikke en universel kategori eller genre. Akavet denaturaliserer i kraft af sin materialitet læseprocessen og stiller derved spørgsmålstegn ved ungdomslitteraturs egenart. Et centralt udsagn i romanen er, at identitetsdannelse er fragmenteret og foreløbig, at det ikke er muligt eller efterstræbelsesværdigt at have en fast væsenskerne, og dette understøttes af materialiteten, forstået som romanens måde at være i verden på. Akavet handler ikke om processen ved at vokse op, mod- 
nes og gennemleve ungdommen for at blive voksen, men romanen demonstrerer, at erhvervelse af personlig integritet fremkommer på blandt andet mediebaserede præmisser. Mikkes ophold i toget og hans usikkerhed om, hvilken destination han er på vej til, kan dermed ses som et sindbillede på en grundlæggende følelse af hjemløshed i tilværelsen, som udgør et vilkår, den unge må og kan håndtere.

Akavet skaber sammen med fredag lørdag søndag og HOMO sapienne ikke traditionelle identitets- og dannelsesfortællinger. I stedet træder en bredere og mere differentieret subjektkonstruktion frem, som indoptager den mediemæssige udvikling og er stadig pågående efter romanernes ophør. De afspejler og materialiserer gennem formens fragmentering identitetsarbejdet som et komplekst og kontinuerligt refleksions- og tolkningsarbejde, hvorfor det ikke er en søgen efter én total og omsiggribende identitet, der er på færde, men erfaringen af konstante forskydninger og udviklinger i følelsen af selvet i udveksling med en mediebåret virkelighed. De tre romaner handler mindre om erhvervelse af identitet, udvikling, modning og social ansvarlighed og mere om at være ung lige her og lige nu og tage livtag med tilværelsen med og imellem medier.

Ungdomsromanerne kan ses som eksempler på, hvordan ungdomslitteratur udvikler sig i dialog med den mediemæssige udvikling og er i gang med at form(er)e sig: dels ved formmæssigt at indoptage og forholde sig til unges liv mellem medier, dels gennem en optagethed af og refleksion over den materielle form med de konsekvenser, det har for i dette tilfælde Akavets samlede udsigelse, som vanskeligt lader sig sætte på én formel. Et afgørende udsagn i romanen er dog et opgør med det konforme, ikke-reflekterede (voksen)liv: "Menneskers opførsel er iscenesat efter deres egne regelsæt" (Andersen, 99) - og i det lys kan den også læses som et opgør med det ubevidste regelsæt, ungdomsromanformen er indlejret i.

\section{Noter}

I Begrebet denaturalisering og de senere i artiklen anvendte begreber destabilisering og uselvfølgeliggørelse kan siges at skrive sig ind i en poststrukturalistisk begrebsramme, som artiklen her ikke baserer sig på. Begreberne anvendes med henblik på at udfordre rodfæstede og bredt antagede forståelser af, hvad fx læsning og ungdomslitteratur er. Den analytiske tilgang er dog ikke diskursanalytisk som i en poststrukturalistisk tilgang. Den materialitetstilgang, som artiklen bygger på, er netop en vægtforskydning fra den sproglige vendings fokus på virkelighedskonstruktion igennem sproget til accentuering af en teksts fysiske gestaltning og væren-i-verden.

2 Som antydet er forståelsen, afgrænsninger og definitioner af ungdomslitteratur i forhold til børne- og voksenlitteratur og ungdomslitteraturs mulige egenart på ingen måde simpel eller entydig. Aktuelt bliver problematikken yderligere kompliceret af fremvæksten af nyere betegnelser og litterære felter som tween- og all age-litteratur og i en dansk kontekst fremkomsten af begrebet YA (young adult). Undersøgelser, differentieringer og konklusioner på dette felt er påtrængende, men ligger udenfor denne artikels rammer.

3 Dette kan iagttages på meget forskellig vis i eksempelvis Henrik Lists Kære fucking dagbog (2009), Caroline Ørsums Kære dumme døde Vik (2015), Jesper Wung-Sungs AEte brøker (2009), Rebecca Bach-Lauritsens Sommerdrenge (2013) og i det stadigt stigende antal graphic novels og remedieringer som fx Jesper Wung-Sung og Søren Jessens Kopierne (2015). 
4 Flanagan arbejder ud fra en posthuman tilgang, og hun analyserer ud fra et stort og engelsksproget tekstkorpus, der også indbefatter science fiction.

5 Trites' analytiske genstandsfelt er primært amerikansk ungdomslitteratur, som ikke har samme tendens til såkaldt 'kompleksitet' forstået som genreblandinger, groteske former, markant sprogbevidsthed og litterær leg med temporalitet og fortælleformer og ikke sjældent indoptagelse af en tabubelagt tematik (Nikolajeva 1996, Kampp 2002), som det kan iagttages i en del nordisk børne- og ungdomslitteratur.

6 I Nina Christensens artikel "Billedbøger og billedbogsforskning under forvandling" (2014) redegøres der for begrebsanvendelsen, og Christensen understreger nødvendigheden af at opfatte (billed)bogen som et medie i lyset af bogmarkedets digitale udvikling.

7 Det er bemærkelsesværdigt, at Hayles ud fra sin overvejende medieteoretiske tilgang finder det nødvendigt at udvikle sit eget begreb til at beskrive det komplekse forhold mellem ord og billede. Hun kunne have anvendt eller differentieret sig fra W.J.T. Mitchells begreb "imagetext", som han har udviklet i sine teoridannelser siden 1980'erne. I forskningen i børnelitteratur har det længe været selvfølgeligt at anskue tekster som bestående af både skrift og billede, og i billedbogsforskningen har Kristin Hallberg udviklet termen "ikonotekst" til at beskrive det samlede udtryk mellem tekst og billede, ligesom Maria Nikolajeva og Carole Scott har udviklet en model for de forskellige relationer mellem den verbale tekst og billede i en "ikonotekst".

8 Hayles anvender ikke begrebet metafiktion, hvilket sikkert er begrundet i hendes medieteoretiske udgangspunkt. Imidlertid anvender hun det litteraturteoretiske begreb palimpsest (dog uden reference til Genette) i Writing Machines og pointerer dets mulige konsekvenser for subjektforståelsen i et af de værker, hun analyserer (Hayles 2002, 110). Akavet har på inskriptionsniveauet på samme måde mange lag, hvilket bidrager til en sammensat subjektkonstruktion af hovedpersonen.

\section{Litteratur}

Andersen, Ronnie (2014): Akavet, København: Høst \& Søn.

Bille, Mikkel og Tim Flohr Sørensen (2012): Materialitet. En indføring i kultur, identitet og teknologi, Frederiksberg: Samfundslitteratur.

Brown, Bill (2010): "Materiality" i W.J.T. Mitchell og Mark B. N. Hansen (red.): Critical Terms for Media Studies, Chicago og London: The University of Chicago Press, 49-63.

Brügger, Niels (2003): "Bogen som medie. Nedslag i bogobjektets historiske transformationer", Passage 48, 77-95.

Christensen, Nina (2003): Den danske billedbog 1950-1999. Teori, analyse, historie, Frederiksberg: Roskilde Universitetsforlag.

Christensen, Nina (2014): "I bevægelse. Billedbøger og billedbogsforskning under forvandling". Tidskrift för litteraturvetenskap 2, 5-19.

Coats, Karen (2004): Looking Glasses and Neverlands. Lacan, Desire, and Subjectivity in Childrens's Literature, Iowa City: University of Iowa Press.

Coats, Karen (2011): "Young Adult Literature. Growing Up, In Theory" i Shelby A. Wolf, Karen Coats, Patricia Enciso og Christine A. Jenkins (red.): Handbook of Research on Children's and Young Adult Literature, New York: Routledge, 315-329.

Damsholt, Tine og Dorte Gert Simonsen og Camilla Mordhorst (2009): Materialiseringer. Nye perspektiver på materialitet og kulturanalyse, Aarhus: Aarhus Universitetsforlag.

Ditlevsen, Christine Lind (2015): fredag lørdag søndag, København: Høst \& Søn. 
Druker, Elina (2008): Modernismens bilder. Den moderna bilderboken i Norden, Stockholm: Makadam. Engell, Sarah (2014): 21 måder at dø på, København: Carlsen.

Ewers, Hans-Heino (2013): "Jugendroman und Jugendromanforschung: eine erneue Bestandaufnahme" i Kinder- und Jugendliteraturforschung 2012/13, Frankfurt: Lang, 71-90.

Falconer, Rachel (2009): The Crossover Novel. Contemporary Children's Fiction and Its Adult Readership, New York: Routledge.

Flanagan, Victoria (2014): Technology and Identity in Young Adult Fiction. The Posthuman Subject, Basingstoke: Palgrave Macmillian.

Gansel, Carsten (2000): “Der Adoleszenzroman. Zwischen Moderne und Postmoderne”, i Günter Lange (red.): Taschenbuch der Kinder- und Jugendliteratur, Baltmannsweiler: Schneider Verlag (2. udgave), 359-398.

Hayles, N. Katherine (2002): Writing Machines, Cambridge: MIT Press.

Hayles, N. Katherine (2004): "Print Is Flat, Code Is Deep: The Importance of Media-Specific Analysis", Poetics Today 25.1, 67-90.

Hayles, N. Katherine (2008): Electronic Literature. New Horizons for the Literary, Indiana: University of Notre Dame Press.

Iser, Wolfgang (1978): The Act of Reading. A Theory of Aesthetic Response, Baltimore and London: The Johns Hopkins University Press.

Iser, Wolfgang (1971): “Indeterminacy and the reader's response in prose fiction" i J. Hillis Miller (red.): Aspects of Narrative, New York og London: Columbia University Press, 1-45.

Kampp, Bodil (2002): Barnet og den voksne i det børnelitterære rum. København: Danmarks Pædagogiske Universitet.

Kampp, Bodil (2004): "Senmoderne ungdomslitteratur" i Nina Christensen, Anna Skyggebjerg og Bodil Kampp: Mod forventning. Analyser af nyere børne- og ungdomlitteratur, København: L\&R Uddannelse, 61-78.

Korneliussen, Niviaq (2014): HOMO sapienne, Nuuk: milik.

Malm, Mats, Barbro Ståhle Sjönell og Petra Söderlund (2009): Bokens materialitet. Bokhistoria och bibliografi, Stockholm: Svenska Vitterhetssamfundet.

McGann, Jerome J. (1991): The Textual Condition, Princeton: Princeton University Press.

Miller, Daniel (2006): “Materiality. An Introduction” i Daniel Miller (red.): Materiality. Durham og London: Duke University Press, 1-50.

Munster, Anna (2014): "Materiality" i Marie-Laure Ryan, Lori Emerson and Benjamin J. Robertson: The Johns Hopkins Guide to Digital Media. Baltimore: Johns Hopkins University Press, 327-330.

Nelson, Teodore H. (1965): "A File Structure for the Complex, The Changing and the Indeterminate" i Proceedings of the ACM 20th National Conference, New York: ACM, 84-100.

Nikolajeva, Maria (1996): Children's Literature Comes of Age. Toward a New Aesthetic, New York: Garland Publishing.

Nikolajeva, Maria (2000): From Mythic to Linear. Time in Children's Literature, Lanham: ChLA and The Scarecrow Press.

Rhedin, Ulla (1992): Bilderboken. På väg mot en teori, Stockholm: Alfabeta.

Rustad, Hans Kristian (2009): “A Four-Sided Model for Reading Hypertext Fiction”, Hyperrhiz 06.

Trites, Roberta Seelinger (2000): Disturbing the Universe. Power and Repression in Adolescent Literature, Iowa City: University Of Iowa Press.

Trites, Roberta Seelinger (2014): Literary Conceptualizations of Growth, Amsterdam/Philadelphia: John Benjamins. 